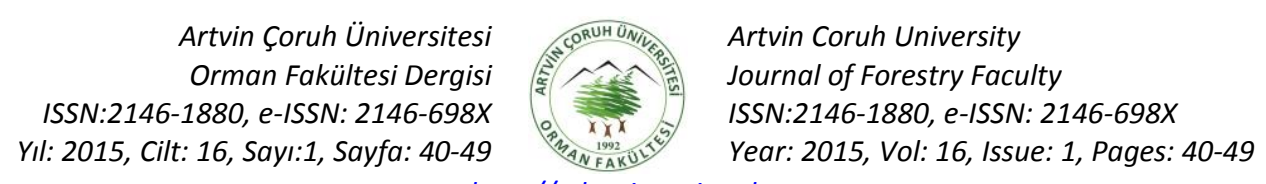

Araştırma makalesi

http://edergi.artvin.edu.tr

\title{
Rekreasyonel tesislerde görsel kalite değerlendirmesi üzerine bir araştırma: Tortum ve Uzundere (Erzurum) örneği
}

\author{
A study on visual quality assessment in recreational facilities: sample of Tortum and Uzundere (Erzurum) \\ Mustafa ÖZGERiş ${ }^{1}$ Faris KARAHAN ${ }^{2}$ \\ Atatürk Üniversitesi, Tortum Meslek Yüksekokulu, Peyzaj ve Süs Bitkileri Programı \\ Atatürk Üniversitesi, Mimarlık ve Tasarım Fakültesi, Peyzaj Mimarlığı Bölümü
}

Özet

Bu araştırmanın amacı Erzurum ili, Tortum ve Uzundere ilçelerindeki bazı rekreasyonel tesislerin görsel kalite değerlendirmesini yapmak ve yöredeki mevcut peyzaj bileşenleri ile görsel kalite arasındaki ilişkiyi değerlendirmektir. Araştırma alanı Erzurum-Artvin (D950-02) karayolunun 64-102. kilometreleri arasındaki bölümünden oluşmaktadır. Çalışmada tesisleri temsil eden 4'er adet fotoğraf kullanılmış ve 200 kişiyle anket çalışması yürütülmüştür. Yapılan değerlendirmede uyumda $(6,58)$, çeşitlilikte $(6,34)$, ortalama canlılıkta $(6,40)$ ve ortalama görsel kalitede $(6,44)$ en yüksek değerlere sahip olan görüntü Yedigöller Alabalık Tesisleri 4 (YP4) olmuştur. En düşük değerlere sahip olan görüntüler ise uyumda $(1,71)$, ortalama canlılıkta $(1,69)$ ve ortalama görsel kalitede $(1,70)$ Aksukapı Dinlenme Tesisleri 1 (AP1), çeşitlilikte $(1,66)$ ise Asmalı Konak Dinlenme Tesisleri 1 (AKP1) olmuştur. Ayrıca araştırmada, ziyaretçilerin peyzaj elemanları bakımından çeşitlilik sunan ve peyzaja ait doğal ve kültürel elemanların birbiriyle uyumlu ve bir bütünlük oluşturduğu görüntüleri görsel yönden daha etkili ve kaliteli olarak değerlendirdikleri sonucuna varılmıştır.

Anahtar Kelimeler: Görsel kalite değerlendirmesi, rekreasyonel tesis, Tortum, Uzundere

\section{Abstract}

The goal of research, is to make visual quality assessment of some recreational facilities in Tortum and Uzundere districts of Erzurum province and to evalue association between visual qualities with existing landscape elements in location. Research areas constitute from part between 64-102 kilometers of Erzurum-Artvin (D950-02) highway. In the study was used four pieces photographs representing recreational facilities and carried out survey study with 200 people. In made evaluation, became the highest values having image Yedigöller Alabalık Tesisleri 4 (YP4) in harmony $(6,58)$, diversity $(6,34)$, average virtality $(6,40)$ and average visual quality $(6,44)$. The having lowest values images became Aksukapı Dinlenme Tesisleri 1 (AP1) in harmony $(1,71)$, average virtality $(1,69)$ and average visual quality $(1,70)$ and Asmalı Konak Dinlenme Tesisleri 1 (AKP1) in diversity $(1,66)$. In addition, in research was concluded that visitors evaluate more effective and high quality for visual aspect images offering diversity in terms of elements landscape and to be compatible with each other and form a unity of natural and cultural elements belonging to landscape.

Keywords: Recreational facility, Tortum, Uzundere, Visual Quality Assessment

\section{GíRiş}

İnsanoğlu tarihin çok eski devirlerinden beri kendine bir yaşam mekânı bulma ve oluşturma eğiliminde olmuştur. Onun bu gayret ve çabaları tabiatın insan ihtiyaçları doğrultusunda olumlu ya da olumsuz yönde şekillenmesini sağlamıştır.

İnsanlığın doğuşu ile çok küçük ölçekte başlayan çevre düzenlemesi (bahçe planlaması) tarih boyunca bilinçli ya da bilinçsiz, olumlu ya da olumsuz yönde gelişerek bugünkü geniş ölçekte çevre düzenlemesi (peyzaj planlaması) kavramının gelişmesine yol açmıştır (Tanrıverdi 2001).

Özellikle dünya nüfusunun artışıyla beraber insanlar dağınık, düzensiz ve genel olarak kırsal yerleşim modellerini terk ederek kentte yaşama ve kentleşme anlayışlarının gelişmesini sağlamıştır. Fakat kentlere doğru yönelen bu aşırı nüfus hareketi, kentler ve

Sorumlu yazar: Mustafa ÖZGERiş, Atatürk Üniversitesi, Tortum Meslek Yüksekokulu, Peyzaj ve Süs Bitkileri Programı, 25440 Uzundere-Erzurum, Türkiye e-mail: m.ozgeris@atauni.edu.tr

DOI: 10.17474 /acuofd. 66885

Bu çalışma Mustafa Özgeriş'in yüksek lisans tezinden üretilmiştir 
kentlerde yaşayan insanlar için birtakım olumsuz sonuçlar doğurmuştur.

Bilimsel, endüstriyel ve teknolojik alandaki gelişmelerin ortaya çıkarmış olduğu plansız ve sağlıksız kentleşme, insanların fiziksel, ruhsal ve sosyo-kültürel yönden pek çok sorununu da beraberinde getirmiştir (Akten 2003). Şehirlerdeki hava, su, toprak kirliliği, nüfus artışının sebep olduğu sıkışıklık, kişisel yükümlülük ve zorunluluklar, toplumsal sorunlardan kaynaklanan sıkıntılar ve yaşamın tekdüze hale gelmesi gibi çeşitli olumsuzluklar insanları yıpratmaktadır (Orel ve Yavuz 2003). Bu durum insanları fiziksel ve psikolojik yönden rahatlayıp, dinlenebilecekleri ve kendilerini yenileyebilecekleri aktivitelere yönlendirmektedir. Günümüzde insanların bu ihtiyaçlarının karşılığı olarak rekreasyon ve turizm kavramları ortaya çıkmıştır.

Rekreasyon Latince "re-tekrar" ve "create-yaratma" sözcüklerinden türemiş olup, bir şeyin yeniden yaratılması ya da kazanılması anlamına gelir (Akten 2003).

Yılmaz vd (1998)'e göre rekreasyon, insanların günlük yaşamları içinde, yaşamış oldukları monotonluktan uzaklaşıp, bedensel ve düşünsel olarak kendilerini yeniden kazanabilmeleri için gerçekleştirdikleri serbest zaman değerlendirmesidir.

Rekreasyon kavramının temelini oluşturan olgu serbest (boş) zamandır ve günümüzde insanlar serbest zamanlarını kişisel tercihlere göre farklı şekillerde değerlendirebilmektedirler (Kozak 2012). Turizm kavramı da serbest zaman değerlendirme etkinliklerinde bir tanesidir. Yani turizm aynı zamanda rekreasyonel bir faaliyettir.

Bulut (2006)'a göre rekreasyon ve turizm olguları; insanların eğlenme, dinlenme, yeniden hayata bağlanma ve çalışma hayatına hazırlanmak için enerji depolama gibi gereksinimlerinden doğmuştur.

Günümüzde, insanların büyük bir çoğunluğu uzun ya da kısa süreli rekreasyonel faaliyetlerinde görsel kalitesi yüksek olan mekanları tercih etmektedirler.
Yani görsellik, rekreasyonel faaliyetlerde alan tercih edilirliğini sağlayan unsurların başında gelmektedir.

Bir alanın görsel etkisi, çevrenin iyi ya da kötü algılanması ve buna bağlı olarak da kullanıcıların bu alandan zevk alıp alamamaları üzerinde doğrudan etkili olmaktadır. Bu nedenle bir proje çalışmasında, daha karar aşamasında, yörenin görsel niteliğinin saptanarak analizinin yapılması, görsel kaynakların korunması için en doğru olan yöntemdir. Bu, çevrenin görsel ve ekolojik yapısının korunmasının yanı sıra gerek çalışmalar sırasında ve gerekse daha sonra ortaya çıkacak masrafların en aza inmesini de sağlayacaktır (Özgüç 1999).

Clay and Daniel (2000)'e göre turizm veya rekreasyonel bağlamda doğal çevrenin başlıca bileşeni, görsel veya manzara kalitesidir. Manzara bakımından önemli peyzajlar sadece onları yaşayan bireye faydalı değillerdir. Alanın çekiciliğine önemli bir katkı sağlarlar, dolayısıyla bölgenin ekonomik faydaları ile ilişkilendirilebilirler. Çünkü görsel karakter, bir turistik/rekreasyonel deneyimin bütün kalitesini etkiler (Kıroğlu 2007; Elinç 2011).

Görsel peyzaj kalitesi, gözlemcinin algısal ve duygusal psikolojik süreçleri ile etkileşim içinde olan belli (görünür) peyzaj özelliklerinin ortak bir ürünüdür. Çevrenin insan üzerindeki davranışa dönüşen bu etkisinin nasıl algılandığı nasıl yorumlandığı ve nasıl değerlendirildiği, görsel algılama süreci sonucunda oluşan "görsel peyzaj kalitesi" olarak tanımlamaktadır. Görsel peyzaj kalitesi "bir peyzajın göreceli olarak estetik kusursuzluğu" olarak da tanımlanabilir ve gözlemcinin beğenisi aracılığı ile ölçülebilir (Lothian 1999; Daniel 2001; Kalın 2004; De La Fuente et. al. 2006; Kıroğlu 2007; Elinç 2011).

Kaptanoğlu (2006)'na göre görsel kalite değerlendirmesi, peyzaja ait görsel bilginin, bir gözlemci tarafından, idealize edilmiş peyzaja uygunluğunun ölçülmesidir (Elinç 2011).

$\mathrm{Bu}$ çalışmanın amacı; rekreasyon ve turizm olguları bakımından birtakım potansiyel kaynak değerlerine 
sahip olan Erzurum ili Tortum ve Uzundere ilçelerindeki bazı rekreasyonel tesislerin görsel kalite analizini yapmak ve yöredeki mevcut peyzaj bileşenleri ile görsel kalite arasındaki ilişkiyi değerlendirmektir.

\section{MATERYAL ve YÖNTEM}

\section{Materyal}

Araştırma Erzurum-Artvin (D950-02) Karayolu yakın çevresinin 64-102. kilometreleri arasındaki bazı rekreasyonel tesislerde yürütülmüştür. $\mathrm{Bu}$ rekreasyonel tesisler; Aksukapı Dinlenme Tesisleri (ADT), Taş Devri Dinlenme Tesisleri (TDDT), Asmalı Konak Dinlenme Tesisleri (AKDT), Pehlivanlı Alabalık Tesisleri (PAT), Uzunburun Yarımadası Dinlenme Tesisleri (UYDT), Şelale Dinlenme Tesisleri (ŞDT) ve Yedigöller (Yıkıklar) Alabalık Tesisleridir (YAT) (Şekil 1).

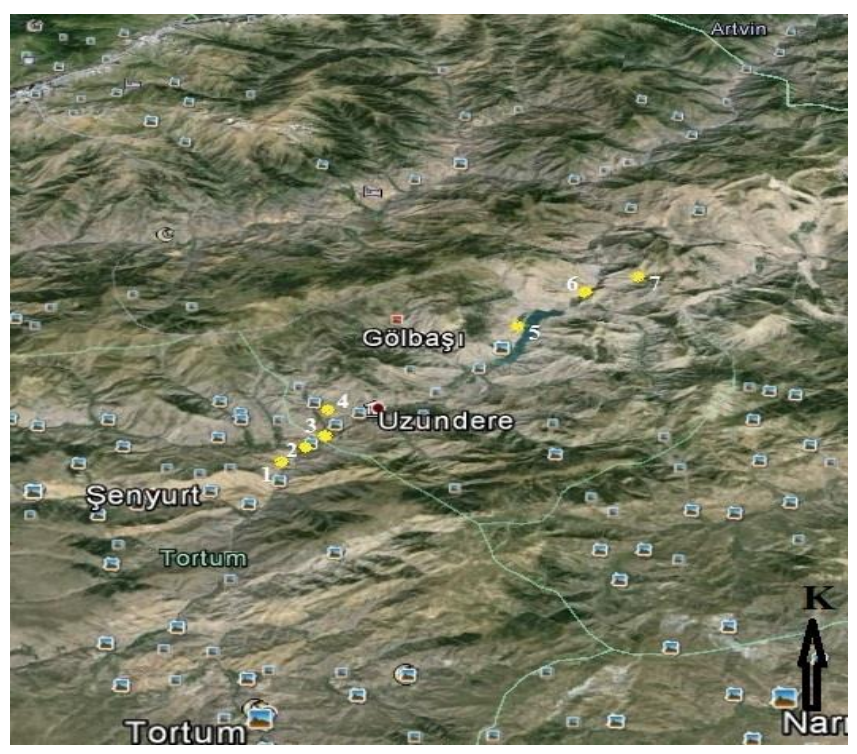

Şekil 1. Rekreasyonel tesislerin genel konumu (1-Aksukapı Dinlenme Tesisleri 2-Asmalı Konak Dinlenme Tesisleri 3-Taş Devri Dinlenme Tesisleri 4-Pehlivanlı Alabalık Tesisleri 5-Uzunburun Yarımadası Dinlenme Tesisleri 6-Şelale Dinlenme Tesisleri 7Yedigöller (Yıkıklar) Alabalık Tesisleri)

Çalışmaya konu olan bu rekreasyonel tesislerinin seçiminde;

- Tesisin yöredeki bilinirliği,

- Tesiste ziyaretçilere sunulan imkanlar (yemeiçme, konaklama, piknik v.s)

- Tesis yoğunluğu

- Tesisin manzara değeri ve yapı mimarisi ve
- Tesisin ulaşılabilirlik durumu gibi kriterler göz önünde bulundurulmuştur.

\section{Yöntem}

Daniel (1976), manzara güzelliğini değerlendirmek amacıyla "biçimsel estetik yaklaşım modeli" ve "psikolojik yaklaşım modelini" birleştirerek "psikofiziksel yaklaşım modelini" oluşturmuştur (Daniel and Boster 1976; Elinç 2011). Bu çalışmada insan algısı ile alanın fiziksel özellikleri (topografya, vejetasyon, su yapısı vb.) arasındaki ilişkileri araştıran psikofiziksel çalışmalar temel alınmıştır (Lothian 1999; Misgav 2000; Wong and Domroes 2005; Çakcı 2007; Bernasconi et. al. 2009; Vouligny et. al. 2009; Elinç 2011).

Araştırma konusunu oluşturan rekreasyonel tesisleri temsil eden görüntüler, dijital fotoğraf makinesi kullanılarak temin edilmiştir. Her bir tesiste 40 'ar adet olmak üzere toplamda 280 adet fotoğraf, vejetasyon örtüsünün en canlı olduğu ilkbahar mevsiminde (23-24 Mayıs 2014) çekilmiştir. Bu fotoğraflardan, tesislerdeki kullanım alanlarını olumlu-olumsuz tüm yönleriyle ortaya koyan ve kullanıcılar tarafından görülme olasılığı en yüksek manzaraların varlığı esas alınarak, 4'er adet fotoğraf (toplamda 28 adet) anket çalışmasında kullanılmıştır (1-AP1 görüntüsündeki toprak yığını, tesisin bulunduğu mevkide meydana gelen trafik kazalarına karşı, işletmecinin tesisi korumaya yönelik olarak almış olduğu bir önlemdir 2YP2 görüntüsündeki mekan işletmeye ait çay bahçesi olarak kullanılmaktadır).

Anketlerin $\% 50$ 'lik kısmı baskı fotoğraflar üzerinden yüz yüze görüşülerek, diğer \%50'lik kısmı ise microsoft power point programı ile hazırlanan slayt gösterisi üzerinden yapılmıştır. Her iki anket metodunda da çalışmaya başlamadan önce katılımcılara puanlama sistemi ve parametre tanımlamalarıyla ilgili gerekli bilgiler verilmiştir. Anket çalışması yöre (TortumUzundere) nüfusunun \%1'ine denk gelen 200 kişi ile yürütülmüştür. 
Anket formları katılımcı profilini ve görsel değerlendirmeyi yapmak amacıyla iki bölümden oluşacak şekilde hazırlanmıştır. I. bölümde katılımcılara demografik özelliklerine yönelik sorular yöneltilmiştir. II. bölümde ise Karahan (2003)'ın uyguladığı üzere katılımcılardan her bir fotoğraf için belirtilen parametrelere uygun olarak değerlendirme yaparak 1 ile 7 arasında puan vermesi istenmiştir. Puanlamada 1 en düşük puanı, 7 ise en yüksek puanı temsil etmiştir.

Çalışmada psikofiziksel değerlendirme metodu kullanıldığından, peyzajın fiziksel yapısı ve kültürel peyzaj elemanlarının doğal peyzaj elemanları ile oluşturduğu kompozisyonun incelenmesi amaçlanmıştır. Bu amaca yönelik olarak uyum, çeşitlilik ve canlılık parametreleri kullanılarak şu şekilde tanımlanmıştır:

- Uyum (U): Fotoğrafta yer alan doğal peyzaj özellikleri ile insan eliyle oluşturulmuş olan kültürel peyzaj özellikleri arasındaki benzerliği ifade etmektedir.

- Çeşitlilik (Ç): Fotoğraftaki peyzaj elemanlarının çok sayıda ve birbirinden farklı olmasını ifade etmektedir.

- Canlılık (O.C): Fotoğraftaki manzaranın ve peyzaj elemanlarının görsel bir etkiye sahip olmasını ve akılda kalıcılığını ifade etmektedir.

Elde edilen anket verileri SPSS 15.0 programına işlenerek her bir fotoğrafın parametre ve ortalama görsel kalite puanları ile standart sapmaları hesaplanmıştır. Uyum ve çeşitlilik parametreleri bağımsız olarak değerlendirmeye tabi tutulurken, canlılık parametresi vejetasyon (v), su (s) ve jeomorfoloji (j) faktörlerine bağlı olarak değerlendirmeye tabi tutulmuş ve bu üç faktörden edilen puanlarla canlılık parametresinin ortalama puanı oluşturulmuştur (C= v+s+j / 3) (Karahan 2003). Fotoğraflara ait görsel kalite (O.G.K) puanlarının hesaplanmasında ise canlılık, uyum ve çeşitlilik parametrelerine ait puanların ortalaması alınmıştır (O.G.K= U+Ç+C / 3).

\section{ARAŞTIRMA BULGULARI}

Anket çalışmasına katılanların \%61'i bay, \%39'u ise bayandır. \%33,5'i 26-35, \%34,5'i 16-25, \%21'i 36-45 yaş grubunda olan katılımcıların büyük çoğunluğu genç ve orta yaş grubunda yer almaktadır. \%27'si öğretmenakademisyen, \%24'ü öğrenci, \%10’u esnaf, \%10'u kamu çalışanı ve $\% 5,5^{\prime} \mathrm{i}$ mimar-mühendis olan katılımcıların, \%51'i üniversite-yüksekokul, \%42'si ise lise mezunudur. Katılımcıların gelir düzeylerine bakıldığında \%31'i 2000-3000 TL arasında, \%22'si 750 TL'nin altında ve $\% 21,5^{\prime} \mathrm{i}$ ise 750-1500 TL arasında ve bir gelire sahip olduklarını belirtmişlerdir.

Çalışmada tesislere ait görüntülerin almış oldukları ortalama parametre ve görsel kalite puanları çizelge 1.'de verilmiştir. Çizelge 1 'de görüldüğü üzere her bir tesisin, en yüksek ortalama görsel kaliteye sahip olan görüntüsü Aksukapı Dinlenme Tesisleri-AP4 $(3,16)$, Asmalı Konak Dinlenme Tesisleri-AKP4 $(2,42)$, Taş Devri Dinlenme Tesisleri-TDP1 (2,33), Pehlivanlı Alabalık Tesisleri-PP2 $(4,91)$, Uzunburun Yarımadası Dinlenme Tesisleri-UP4 (4,82), Şelale Dinlenme Tesisleri-ŞP2 $(5,86)$ ve Yedigöller Alabalık Tesisleri-YP4 $(6,44)$ olmuştur (Şekil 2).

Bütün görüntüler içerinde en yüksek ortalama görsel kaliteye sahip olan görüntü Yedigöller Alabalık Tesislerine ait YP4 görüntüsü olmuştur. YP4 görüntüsü uyum parametresinde 6,58, çeşitlilikte 6,34 ve ortalama canlılıkta 6,40 puan alırken, su faktöründe 6,87 , jeomorfolojide 6,70 ve vejetasyonda 5,62 puan almıştır. 
Çizelge 1. Tesislere ait görüntülerin parametre ve ortalama görsel kalite puanları

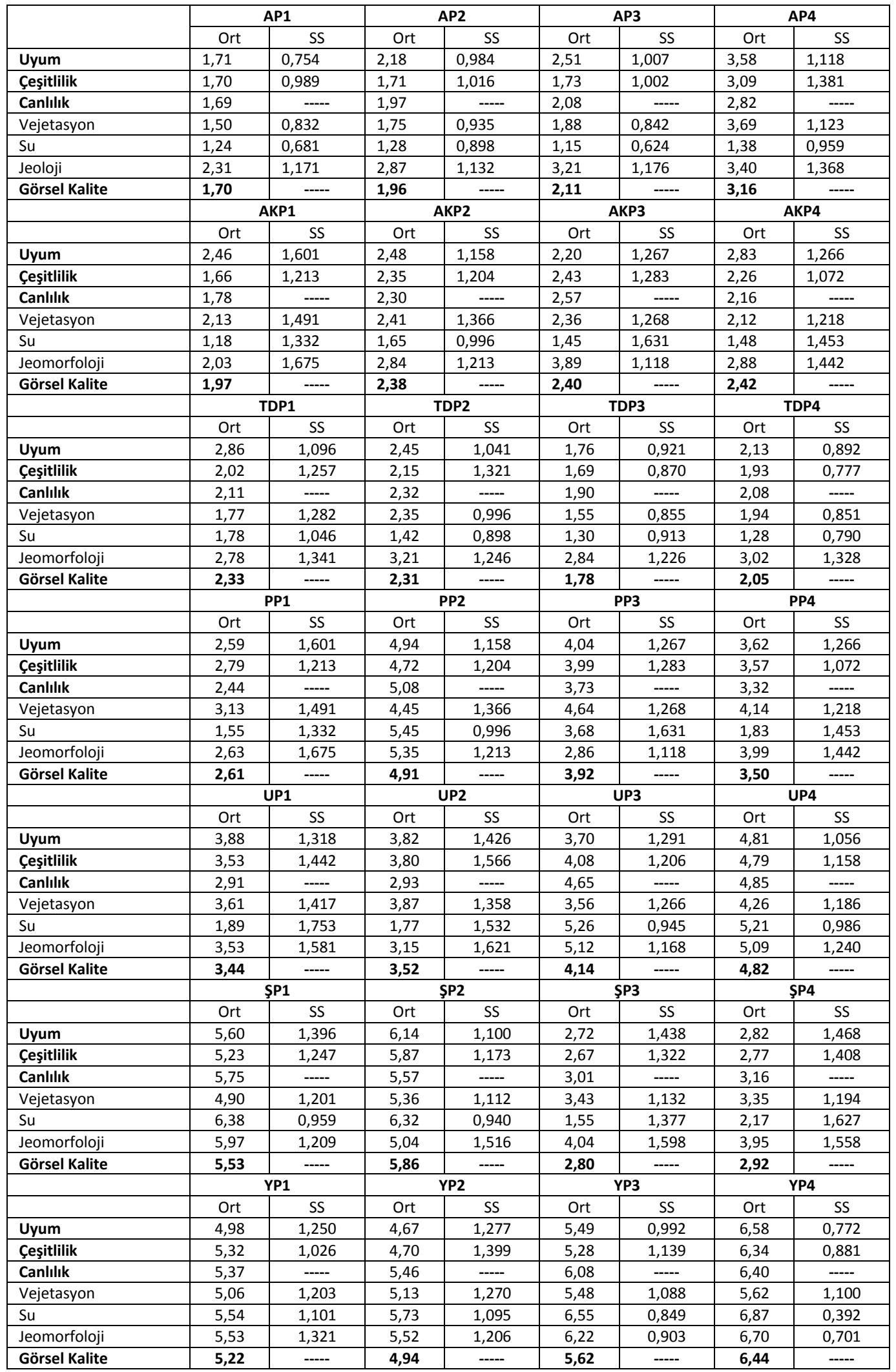



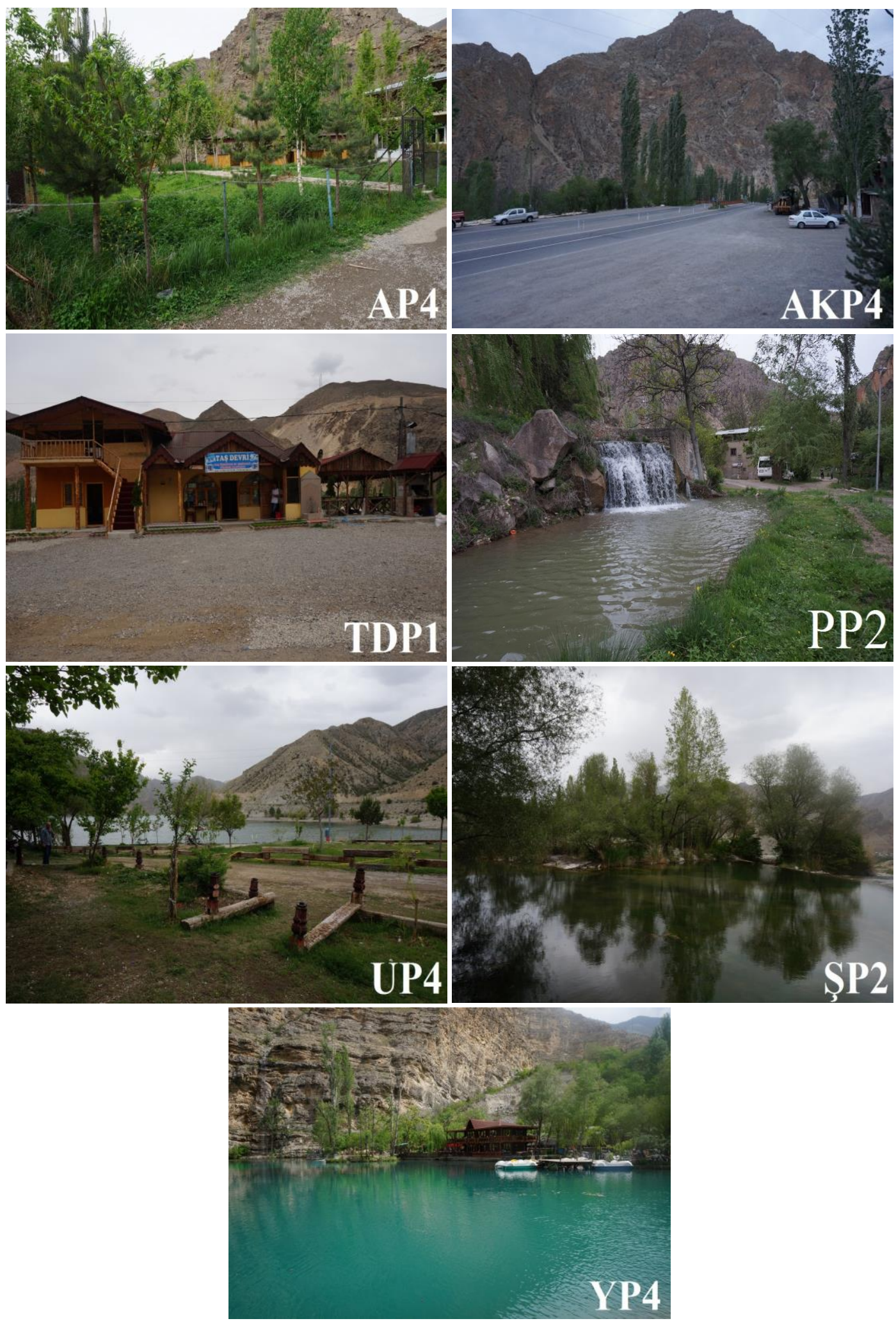

Şekil 2. Tesislerin en yüksek ortalama görsel kaliteye sahip olan görüntüleri 
Her bir tesisin en düşük ortalama görsel kaliteye sahip olan görüntüsü ise Aksukapı Dinlenme Tesisleri-AP1 $(1,70)$, Asmalı Konak Dinlenme Tesisleri-AKP1 $(1,97)$, Taş Devri Dinlenme Tesisleri-TDP3 $(1,78)$, Pehlivanlı Alabalık Tesisleri-PP1 $(2,61)$, Uzunburun Yarımadası Dinlenme Tesisleri-UP1 $(3,44)$, Şelale Dinlenme Tesisleri-ŞP3 $(2,80)$ ve Yedigöller Alabalık Tesisleri-YP2 $(4,94)$ olmuştur (Şekil 3).

Bütün görüntüler içerisinde en düşük ortalama görsel kaliteye sahip olan görüntü Aksukapı Dinlenme Tesislerine ait AP1 görüntüsü olmuştur. AP1 görüntüsü uyum parametresinde 1,71, çeşitlilikte 1,70 ve canlılıkta 1,69 puan alırken, su faktöründe 1,24, jeomorfolojide 2,31 ve vejetasyonda 1,50 puan almıştır.

\section{TARTIŞMA VE SONUÇ}

Bu çalışma Erzurum-Artvin (D950-02) Karayolunun 64102. kilometreleri arasındaki bazı rekreasyonel tesisler üzerinde yürütülmüştür. Çalışmanın amacı Tortum ve Uzundere ilçelerindeki bazı rekreasyonel tesislerin görsel kalite düzeylerini tespit etmek yöredeki mevcut peyzaj bileşenleri ile görsel kalite arasındaki ilişkiyi değerlendirmektir.

Araştırmada tesisler yapı mimarisinin çevresel dokuya olan uyumluluğu, peyzaj elemanlarının çeşitliliği ve canlılığı yönünden incelenmiştir. Görüntülerin canlılık yönünden incelenmesinde, yörenin kendine özgü topoğrafik-jeolojik yapısı, vejetasyon örtüsü ve su varlığı göz önünde bulundurulmuştur.

Çalışmada 7 farklı tesise ait 28 adet görüntü içerinde en yüksek ortalama görsel kaliteye sahip olan görüntü, Yedigöller Dinlenme Tesislerine ait YP4 görüntüsü olmuştur. YP4 görüntüsüne bakıldığında uyum parametresinde 6,58 puan aldığı görülmektedir. Bu durumda görüntüdeki yapı mimarisinin doğal peyzaj elemanları ile uyumlu olmasının etkili olduğu düşünülmektedir.

Demirci (2010) çalışmasında manzara görsel tercih puanları yüksek olan görüntülerin uyum parametre değerlerini de yüksek bulmuştur. YP4 görüntüsünün uyum parametresi puanının yüksek olmasının ortalama görsel kalite puanını da olumlu yönde etkilediği değerlendirilmiştir.

YP4 görüntüsünün su, vejetasyon ve jeomorfoloji unsurlarıyla çeşitlilik $(6,34)$ sergilediği görülmektedir. Hunziker and Kienast (1999)'a göre çeşitlilik ve manzara değeri arasında önemli bir ilişki vardır (De La Fuente et. al. 2006; Kıroğlu 2007). YP4 görüntüsündeki su varlığı, su ile bütünleşmiş vejetasyon örtüsü, ilginç jeolojik yapıya sahip olan dağlar ve bunlara yapı, doku ve renk bakımından uyumlu olan mimari ünite ortalama görsel kaliteyi olumlu yönde etkilemiştir.

Tüm görüntüler içerisinde en düşük ortalama görsel kaliteye sahip olan görüntü ise Aksukapı Dinlenme Tesislerine ait AP1 görüntüsü olmuştur. AP1'in görsel kalitesinin düşük olmasındaki başlıca etmenlerden biri mimari ünitenin yapı, doku ve renk bakımından çevre ile uyumluluk $(1,71)$ arz etmemesi, bütünlük oluşturmamasıdır. Özellikle veranda dikmelerinin renk bakımından doğa ile bir ahenk oluşturmadığı görülmektedir. Görüntüdeki toprak yığını çirkin bir görüntü oluşturarak, manzara kalitesini düşürmüştür. Ayrıca görüntünün su ve vejetasyon varlığı bakımından zengin olmaması çeşitlilik $(1,70)$ ve canlılık $(1,69)$ ortalamasını, düşürerek görsel kaliteyi olumsuz yönde etkilemiştir.

Araştırma göstermektedir ki; görüntülerdeki peyzaj elemanlarının çok sayıda ve birbirinden farklı olması çeşitlilik parametresine verilen puanları olumlu yönde etkilemiştir. Nitekim peyzaj elemanları bakımından AP1 görüntüsüne göre daha zengin durumda olan YP4 görüntüsü, çeşitlilik parametresi bakımından 6,34 puan alırken AP1 görüntüsü 1,70 puan almıştır.

Doğal ve kültürel peyzaj elemanlarının bütünlük oluşturması uyum ve canlılık parametrelerinin puanlarını artırmıştır. YP4 ve AP1 görüntülerinin uyum ve canlılık puanları karşılaştırıldığında bu durum açık bir şekilde görülmektedir. 


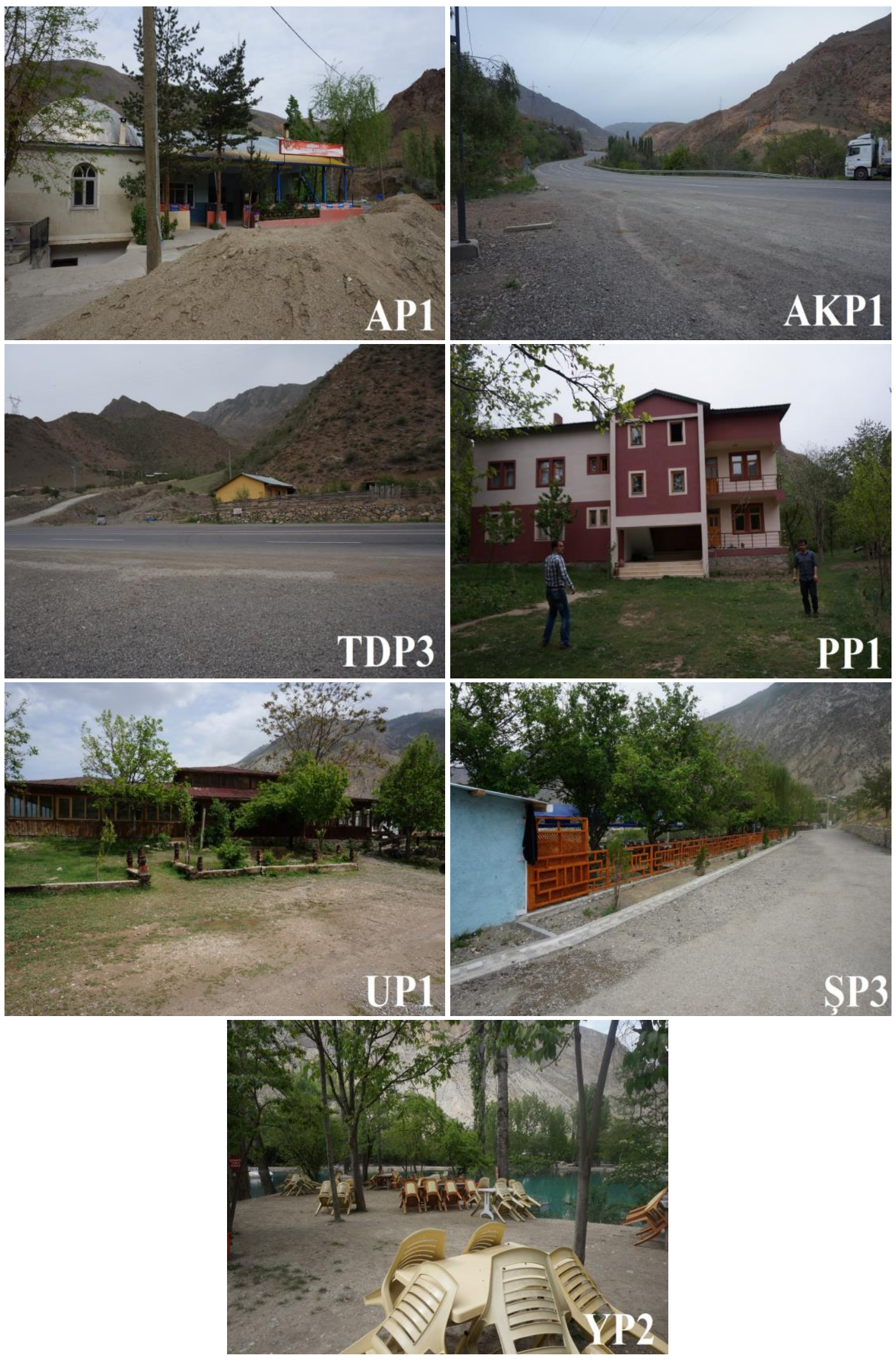

Şekil 3. Tesislerin en düşük ortalama görsel kaliteye sahip olan görüntüler 
Çalışmada genel olarak görüntülerin vejetasyon puanlarının düşük olduğu görülmüştür. Vejetasyon dokusunun düşük puanlar aldığı görüntülerin canlılık ve çeşitlilik parametrelerine ait puanların da düşük olduğu görülmüştür. Bununla beraber görüntülerdeki su varlığının da manzaranın daha canlı ve peyzaj elemanları bakımından daha çeşitli algılanmasını sağlamıştır. Kıroğlu (2007)'ye göre de su oranının görüntüdeki miktarı (\%) arttıkça manzara güzelliği puanının, algılanan görsel güzelliğin de arttığı ortaya çıkmıştır. Nitekim Bulut vd (2010) çalışmalarında su faktörünün önemli bir görsellik unsuru olduğunu; uyum ve canlılık parametrelerinin ise görsel kalite üzerinde önemli etkilerinin bulunduğunu belirtmişlerdir.

Sonuç olarak ziyaretçilerin peyzaj elemanları bakımından çeşitlilik sunan, su ve vejetasyon örtüsü bakımından zengin ve peyzaj elemanlarının doğa ile uyumlu olduğu görüntüleri, görsellik yönünden kaliteli ve etkili olarak algıladıkları değerlendirilmiştir. Bunun yanında araştırmaya konu olan rekreasyonel tesislerin görsel yönden daha etkileyici ve çekici bir duruma gelebilmeleri için;

- Çevresel doku ile uyumlu bir mimari yapı anlayışının benimsenmesinin,

- Tesislerdeki çirkin görüntülerin ortadan kaldırılmasının ve

- Bitkilendirme çalışmalarının yürütülmesinin gerekli olduğu önerilmiştir.

\section{KAYNAKLAR}

Akten M (2003) Isparta Ilindeki Bazı Rekreasyon Alanlarının Mevcut Potansiyellerinin Belirlenmesi. Süleyman Demirel Üniversitesi Orman Fakültesi Dergisi, Seri: A (2), 115-132.

Bernasconi C, Strager MP, Maskey V, Hasanmyer M (2009) Assessing Public Preferences for Design and Environmental Attributes of An Urban Automated

Transportation System. Landscape and Urban Planning 90, 155167.

Bulut Z (2006) Kemaliye (Erzincan) Illçesi ve Yakın Çevresinin Alternatif Turizm Kapsamında Rekreasyonel Turizm Potansiyelinin Belirlenmesi. Doktora Tezi, Atatürk Üniversitesi Fen Bilimleri Enstitüsü, Erzurum.
Bulut Z, Karahan F, Sezen I (2010) Determining Visual Beauties of Natural Waterscapes: A Case Study For Tortum Valley (Erzurum/Turkey). Scientific Research and Essay 5 (2), 170-182.

Bulut Z, Sezen I, Karahan F (2010) Determination of Spring Visual Ceremonies of Urban Fruit Trees and Shrubs: A Case Study From Erzurum(Turkey). Journal of Food Agriculture \& Environment, 8 (1), 289-296.

Clay GR, Daniel TC (2000) Scenic landscape assesssment: The Effects of Land Management Jurisdiction on Public Perception of Scenic Beauty. Landscape and Urban Planning, 49 (1-2), 113.

Çakcı I (2007) Peyzaj Planlama Çalışmalarında Görsel Peyzaj Değerlendirmesine Yönelik Bir Yöntem Araştırması. Doktora Tezi, Ankara Üniversitesi Fen Bilimleri Enstitüsü, Ankara.

Daniel TC (2001) Whither scenic beauty? Visual landscape quality assessment in the 21st century. Landscape and Urban Planning, 54 (1-4), 267-281.

Daniel TC, Boster RS (1976) Measuring Landscape Esthetics: The Scenic Beauty Estimation Method. USDA Forest Service Research Paper RM-167 Rocky Mountain Forest and Range Experiment Station, $69 \mathrm{p}$, USA.

De La Fuente G, Atauri JA, De Lucio JV (2006) Relationship between landscape visual attributes and spatial pattern indices: $A$ test study in Mediterranean-climate landscapes. Landscape and Urban Planning, 77 (4), 393-407.

Demirci E (2010) Atatürk Üniversitesi Yerleşkesinin Görsel Kalite Yönünden Değerlendirilmesi. Y. Lisans Tezi, Atatürk Üniversitesi Fen Bilimleri Enstitüsü, Erzurum.

Elinç H (2011) Görsek Kalite Değerlendirmesi Yöntemi ile Antalya İli Alanya ilçesindeki Abdurrahman Alaeddinoğlu ve Alanya Belediye Başkanları Kent Parklarının İrdelenmesi. Y. Lisans Tezi, Selçuk Üniversitesi Fen Bilimleri Enstitüsü, Konya.

Hunziker M, Kienast F (1999) Potential İmpacts of Changing Agricultural Activities on Scenic Beauty - A Prototypical Technique for Automated Rapid Assessment. Landscape Ecology, 14, 161-176.

Kalın A (2004) Çevre Tercih ve Değerlendirmesinde Görsel Kalitenin Belirlenmesi ve Geliştirilmesi Trabzon Sahil Bandı Örneği. Doktora Tezi, Karadeniz Teknik Üniversitesi Fen Bilimleri Enstitüsü, Trabzon.

Kaptanoğlu Çağlayan AY (2006. Peyzaj Değerlendirmesinde Görsel Canlandırma Tekniklerinin Kullanıcı Tercihine Etkileri. Doktora Tezi, İstanbul Üniversitesi Fen Bilimleri Enstitüsü, İstanbul.

Karahan F (2003) Erzurum-Rize Karayolu Koridoru Peyzaj Planlaması ve Manzara Yolu Olarak Kullanıma Sunulma Olanakları. Doktora Tezi, Atatürk Üniversitesi Fen Bilimleri Enstitüsü, Erzurum.

Kıroğlu E (2007) Erzurum Kenti ve Yakın Çevresindeki Bazı Rekreasyon Alanlarının Görsel Peyzaj Kalitesi Yönünden Değerlendirilmesi. Y. Lisans Tezi, Atatürk Üniversitesi Fen Bilimleri Enstitüsü, Erzurum. 
Kozak N (2012) Genel Turizm Bilgisi, Anadolu Üniversitesi Yayınları No: 2472, 152 s, Eskişehir.

Lothian A (1999) Landscape and The Philosophy of Aesthetics: Is Landscape Quality Inherent In The Landscape or in The Eye of The Beholder? Landscape and Urban Planning, 44 (4), 177-198.

Misgav A (2000) Visual Preference of The Public for Vegetation Groups in Israel. Landscape and Urban Planning, 48 (3-4), 143159.

Orel F Yavuz MC (2003) Rekreasyonel Turizmde Müşteri Potansiyelinin Belirlenmesine Yönelik Bir Pilot Çalışma. Çukurova Üniversitesi Sosyal Bilimler Enstitüsü Dergisi, 11 (11), 61-76.

Özgeriş M (2014) Tortum ve Uzundere'deki Rekreasyonel Tesislerin Görsel Kalite Analizi. Y. Lisans Tezi, Atatürk Üniversitesi Fen Bilimleri Enstitüsü, Erzurum.

Özgüç IM (1999) TEM Hadımköy-Kınalı Arası Peyzaj Planlaması Üzerinde Görsel Araştırmalar. iü Orman Fakültesi Dergisi, A Serisi, 49 (2), 115-132.
Polat Z, Acar C (2010) Peyzajda Neden Görsel Kalite Analizi Yaparı? Artvin Çoruh Üniversitesi Orman Fakültesi Dergisi, 10 (2), 1929.

Tanrıverdi F (2001) Peyzaj Mimarlığı Bahçe Tanıtımı Temel Illkeleri ve Uygulama Metotları. Erzurum

Vouligny É, Domon G, Ruiz J (2009) An Assessment of Ordinary Landscapes by An Expert and by its Residents: Landscape Values in Areas of Intensive Agricultural Use. Land Use Policy, 26 890-900.

Wong KK, Domroes M (2005) The Visual Quality of Urban Park Scenes of Kowloon Park, Hong Kong: Likeability, Affective Appraisal, And Cross-Cultural Perspectives. Environment And Planning, 32, 617- 632.

Yılmaz H, Kırzıoğlu MI, Şimşek EE (1998) Oltu Kent Merkezi ve Yakın Çevresinin Rekreasyonel Potansiyeli Üzerine Bir Araştırma. Geçmişten Geleceğe Oltu ve Çevresi Sempozyumu Bildiriler Kitabı, 240-253 